\begin{tabular}{|l|l|l|}
\hline Received : 27/03/2021 & Accepted: 20/06/2021 & Published : 30/06/2021
\end{tabular}

\title{
Analisa Kerugian Head Akibat Perluasan Dan Penyempitan Penampang Pada Sambungan 90
}

\author{
Ahmad Yani ${ }^{1)}$, Ratnawati ${ }^{2)}$, Ardyanto Darmanto ${ }^{3)}$ \\ ${ }^{1,2}$ Program Studi Teknik Mesin Sekolah Tinggi Teknologi Industri Bontang. \\ 1,2 Jl. Bridgjen KatamsoNo. 40 Bontang - Indonesia 75311 \\ ${ }^{3}$ Program Studi Teknik Otomotif Kendaraan Tempur Politeknik Angkatan Darat \\ ${ }^{3} J$ l. Kesatrian Pusdik Arhanud Pussenarh, Kodiklat TNI AD, Desa Pendem Kecamatan \\ Junrejo, Kota Batu, Malang, Jawa Timur \\ (Email: azahabr@gmail.com)
}

\begin{abstract}
PVC pipe (polyvinyl chloride), galvanized, and stainless steel are types of pipes that are widely used, especially for delivering clean water to people's homes or in the industrialized world. This research was conducted by collecting data such as: flow rate (Q), pressure height (h), pipe flow velocity (v), time (s), and head loss (H), data were collected and calculated to determine pressure loss, effect variations in discharge changes and loss coefficients. From the experimental results, it was found that for the narrowing of the cross section at a discharge of 25 liters / second the value of the head loss was greater, which was located in the galvanic pipe, namely 0.09568, then followed by a discharge of 20 liters / second the value was 0.06454 and a discharge of 15 ltr / second the value was 0,03723 . While the smallest value in panampang narrowing lies in PVC pipe, at a discharge of $25 \mathrm{ltr} / \mathrm{second}$ the value is 0.05957, at a discharge of $20 \mathrm{ltr} / \mathrm{second}$ the value is 0.03989 and at a discharge of $15 \mathrm{ltr} / \mathrm{second}$ the value is 0.02303. Likewise in the expansion of the cross-section, the greatest value lies in the galvanized pipe. For a debit of $25 \mathrm{ltr} / \mathrm{second}$ the value obtained is 0.03526, a debit of $20 \mathrm{ltr} / \mathrm{second}$ the value is 0.02355 , a debit of $15 \mathrm{ltr} /$ second the value is 0.01352. While the smallest value is located on the stainless steel pipe, the value is 0.02688 for the flow rate of 25 liters / second, the value for 20 liters / second is 0.01811, the value for 15 liters / second is 0.01044 .
\end{abstract}

Key words: elbow connection (experiment) with (theory), loss coefficient, head loss, and reynolds number

\begin{abstract}
Abstrak
Pipa PVC (polivinil chloride), galvanis, dan stainless stell merupakan jenis-jenis pipa yang banyak digunakan terutama untuk mengalirkan air bersih kerumah-rumah penduduk ataupun didunia industri. Penelitian ini dilakukan dengan cara mengumpulkan data seperti : debit aliran (Q), tinggi tekanan (h), kecepatan aliran pipa (v), waktu (s), dan kerugian head (H), data dikumpulkan dan dihitung untuk mengetahui kehilangan tekanan, pengaruh variasi perubahan debit dan koefisien kerugian. Dari hasil eksperimen diperoleh bahwa untuk penyempitan penampang pada debit 25 liter/detik nilai kerugian headnya lebih besar terletak pada pipa galvanis yaitu 0,09568, kemudian diikuti dengan debit 20 liter/detik nilainya adalah 0,06454 dan debit 15 ltr/detik nilainya adalah 0,03723 . Sedangkan nilai yang paling kecil pada penyempitan panampang terletak pada pipa PVC, pada debit $25 \mathrm{ltr} /$ detik nilainya adalah 0,05957, pada debit $20 \mathrm{ltr} /$ detik nilainya adalah 0,03989 dan pada debit $15 \mathrm{ltr} /$ detik nilainya adalah 0,02303. Begitu pula pada perluasan penampang, nilai yang paling besar terletak pada pipa galvanis. Untuk debit 25 ltr/detik nilai yang didapat adalah 0,03526, debit 20 ltr/detik nilainya adalah 0,02355 , debit 15 ltr/detik nilainya adalah 0,01352 . Sedangkan nilai yang paling kecil terletak pada pipa stainless steel, pada debit 25 liter/detik nilainya adalah 0,02688, debit 20 liter/detik nilainya adalah 0,01811, debit 15 liter/detik nilainya adalah 0,01044 .
\end{abstract}

Kata kunci: sambungan elbow (eksperimen) dengan (teori), koefisien kerugian, kerugian head, dan bilangan reynolds.

\section{Pendahuluan}

Ilmu pengetahuan dan teknologi akan berkembang apabila dibarengi dengan mengadakan penelitian, pengujian dan analisa pada berbagai disiplin ilmu pengetahuan. 
Mekanika fluida sebagai bagian dari ilmu pengetahuan merupakan salah satu contoh yang perlu mendapat perhatian karena penerapannya luas.

Setiap hari kita semua selalu berhubungan dengan fluida hampir tanpa sadar. Banyak gejala alam yang indah dan menakjubkan, seperti bukit-bukit yang dalam, terjadi akibat gayagaya yang ditimbulkan oleh aliran fluida. Semua fluida mempunyai atau menunjukkan sifatsifat atau karateristik yang penting dalam dunia rekayasa.

Penerapan pinsip-prinsip mekanika fluida dapat dijumpai pada bidang industry, transportasi maupun bidang keteknikan lainnya. Namun dalam penggunaannya selalu terjadi kerugian energi. Dengan mengetahui kerugian energi pada suatu sistem yang memanfaatkan fluida mengalir sebagai media, akan menentukan tingkat efesiensi penggunaan energi.

Bentuk-bentuk kerugian energi pada aliran fluida antara lain dijumpai pada aliran dalam pipa. Kerugian-kerugian tersebut diakibatkan oleh adanya gesekan dengan dinding, perubahan luas penampang, sambungan, katup-katup, belokan pipa dan kerugian-kerugian khusus lainnya. Pada belokan pipa atau lengkungan, kerugian energi aliran yang terjadi lebih besar dibandingkan dengan pipa lurus.

Dengan mengetahui kehilangan atau kerugian energi dalam suatu sistem atau instalasi perpipaan yang memanfaatkan fluida mengalir sebagai media, efisiensi penggunaan energi dapat ditingkatkan sehingga diperoleh keuntungan yang maksimal. Salah satu bagian dari instalasi perpipaan yang dapat menyebabkan kerugian-kerugian adalah belokan pipa dengan sudut-sudut tertentu misalnya sudut $45^{\circ}$, sudut $90^{\circ}$ dan sudut $180^{\circ}$

\section{Tinjauan Teori}

Fluida merupakan suatu zat/bahan yang dalam keadaan setimbang tak dapat menahan gaya atau tegangan geser (shear force). Dapat pula didefinisikan sebagai zat yang dapat mengalir bila ada perbedaan tekanan dan atau tinggi. Suatu sifat dasar fluida nyata, yaitu tahanan terhadap aliran yang diukur sebagai tegangan geser yang terjadi pada bidang geser yang dikenai tegangan tersebut adalah viskositas atau kekentalan/kerapatan zat fluida tersebut [1].

Berdasarkan wujudnya, fluida dapat dibedakan menjadi dua bagian yaitu:

1. Fluida gas, merupakan fluida dengan partikel yang renggang dimana gaya tarik antara molekul sejenis relatif lemah dan sangat ringan sehingga dapat melayang dengan bebas serta volumenya tidak menentu.

2. Fluida cair, merupakan fluida dengan partikel yang rapat dimana gaya tarik antara molekul sejenisnya sangat kuat dan mempunyai permukaan bebas serta cenderung untuk mempertahankan volumenya.

Penentuan aliran fluida cair laminer atau turbulen ditentukan oleh Reynolds number (bilangan Reynolds). Teori Reynolds merumuskan bahwa untuk aliran internal (internal flow) atau aliran yang mengalir dalam pipa, jenis aliran yang terjadi dapat diketahui dengan mendapatkan bilangan Reynoldsnya [1] dari persamaan:

$$
\operatorname{Re}=\frac{V x D}{v}
$$

Dimana : $\quad \mathrm{V}=$ kecepatan aliran $(\mathrm{m} / \mathrm{s})$

$\mathrm{D}=$ diameter hidraulik $(\mathrm{m})$

$\mathrm{v}=$ viskositas kinematis $\left(\mathrm{m}^{2} / \mathrm{s}\right)$

Jenis aliran berdasarkan bilangan Reynolds untuk aliran internal :

1. $\operatorname{Re}<2300$, aliran adalah laminar

2. $\operatorname{Re}>4000$, aliran adalah turbulen

3. $2300<\operatorname{Re}<4000$, aliran adalah transisi 
Ada berbagai macam faktor yang mempengaruhi hilangnya energi di dalam pipa Jenis-jenis sambungan ikut mempengaruhi hilangnya energi pada pipa. Dengan adanya sambungan dapat menghambat aliran normal dan menyebabkan gesekan tambahan. Pada pipa yang pendek dan mempunyai banyak sambungan, fluida yang mengalir di dalamnya akan mengalami banyak kehilangan energi [2].

Dalam sistem pipa salah satu konstruksinya adalah menggunakan sambungan yang berfungsi untuk membelokan arah aliran fluida ke suatu tempat tertentu. Salah satu efek yang muncul pada aliran ketika melewati suatu sambungan yang berkaitan dengan pola aliran adalah adanya ketidakstabilan aliran atau fluktuasi aliran. Fluktuasi aliran yang terjadi terus menerus pada belokan pipa akan memberikan beban impak secara acak pada sambungan tersebut. Akibat pembeban impak secara acak yang berlangsung terus menerus bisa menyebakan getaran pada pipa.

Cara Penyambungan Pipa :

a. Pengelasan

Jenis pengelasan yang dilakukan adalah tergantung pada jenis pipa dan penggunaannya, misalnya pengelasan untuk bahan stainless steel menggunakan las busur gas wolfram, dan untuk pipa baja karbon digunakan las metal.

b. Ulir (threaded)

Penyambungan ini digunakan pada pipa yang bertekanan tidak terlalu tinggi. Kebocoran pada sambungan ini dapat dicegah dengan menggunakan gasket tape pipe. Umumnya pipa dengan sambungan ulir digunakan pada pipa dua inci ke bawah.

c. Menggunakan Flens (flange)

Kedua ujung pipa yang akan disambung dipasang flens kemudian diikat dengan baut. Persamaan kontinuitas diperoleh dari hukum kekekalan massa yang menyatakan bahwa untuk aliran yang stasioner massa fluida yang melalui semua bagian dalam arus fluida tiap satuan waktu adalah sama, dan dinyatakan [3] dengan:

$$
m=\rho_{1} \cdot Q_{1}=\rho_{2} \cdot Q_{2}=\text { konstan }\left(\frac{\mathrm{kg}}{\mathrm{s}}\right)
$$

Untuk aliran yang tidak termampatkan $(\rho=$ konstan $)$ maka persamaan di atas menjadi

$$
\begin{aligned}
& \mathrm{Q}_{1}=\mathrm{Q}_{2} \\
& \mathrm{~A}_{1} \cdot \mathrm{V}_{1}=\mathrm{A}_{2} \cdot \mathrm{V}_{2}
\end{aligned}
$$

Akibat dari gerakan fluida maka dapat menimbulkan atau menghasilkan energi, terutama energi mekanik yaitu sebagai akibat dari kecepatan fluida (energi kinetis) dan dari tekanannya (energi potensial) serta elevasi (energi potensial dari elevasi). Dalam mekanika fluida terutama bila memperhatikan sifat-sifat fluida dengan mengabaikan compressibility, , maka akan didapatkan energi spesifik atau energi per satuan berat fluida (E) sebagai berikut [4]:

$$
E=\frac{V^{2}}{2 g}+\frac{P}{p g}+Z
$$

Jika aliran tetap/tenang pada suatu fluida ideal yang terletak antara 2 titik pada suatu aliran lanar akan mempunyai energi spesifik yakni E1 dan E2 dari persamaan diatas maka dapat juga dituliskan sebagai berikut :

$$
\mathrm{E}_{1}=\mathrm{E}_{2}
$$




$$
\frac{V_{1}^{2}}{2 g}+\frac{P_{1}}{\rho g}+Z_{1}=\frac{V_{2}^{2}}{2 g}+\frac{P_{2}}{\rho g}+Z_{2}(m)
$$

Menurut [3], hukum kedua Newton yang menyatakan perubahan momentum suatu benda itu sebanding dengan gaya yang bekerja pada benda tersebut. Dengan kata lain momentum aliran fluida terjadi karena adanya perubahan kecepatan aliran

$$
\mathrm{F}=\rho \cdot \mathrm{Q} \cdot\left(\mathrm{V}_{2}-\mathrm{V}_{1}\right) \quad(\mathrm{N})
$$

Tabel 1. Kekasaran rata-rata pipa komersial

\begin{tabular}{|c|c|c|}
\hline \multirow{2}{*}{$\begin{array}{c}\text { Permukaan } \\
\text { Koefisien Kekasaran Mutlak }\end{array}$} & \multicolumn{2}{|c|}{ K - } \\
\cline { 2 - 3 } (M) 10 -3 & (Kaki) \\
\hline $\begin{array}{c}\text { Tembaga, Timbal, Kuningan,Aluminium } \\
\text { (baru }\end{array}$ & $0,001-0,002$ & $(3,33-6,7) 10^{-6}$ \\
\hline Pipa PVC dan Plastik & $0,0015-0,007$ & $(0,5-2,33) 10^{-5}$ \\
\hline Stainless steel & 0.015 & $5 \times 10^{-5}$ \\
\hline Baja komersial pipa & $0,045-0,09$ & $(1,5-3) 10^{-4}$ \\
\hline Membentang baja & 0.015 & $5 \times 10^{-5}$ \\
\hline Weld baja & 0.045 & $1.5 \times 10^{-4}$ \\
\hline Baja galvanis & 0.15 & $5 \times 10^{-4}$ \\
\hline Berkarat baja (korosi) & $0,15-4$ & $(5-133) 10^{-4}$ \\
\hline Baru besi cor & $0,25-0,8$ & $(0.82-2.62) 10^{-4}$ \\
\hline Dikenakan besi cor & $0,8-1,5$ & $(2,7-5) 10^{-3}$ \\
\hline Rusty besi cor & $1.5-2.5$ & $(5-8,3) 10^{-3}$ \\
\hline Lembar besi cor atau aspal & $0,01-0,015$ & $(3,33-5) 10^{-5}$ \\
\hline Merapikan semen & 0.3 & $1 \times 10^{-3}$ \\
\hline Biasa beton & $0,3-1$ & $(1-3,33) 10^{-3}$ \\
\hline Beton kasar & $0,3-5$ & $(1-16,7) 10^{-3}$ \\
\hline Terencana kayu & $0,18-0,9$ & $0.59-2.95$ \\
\hline Biasa kayu & 5 & $16.7 \times 10^{-3}$ \\
\hline
\end{tabular}

Untuk setiap sistem pipa, selain kerugian tipe moody yang dihitung untuk seluruh panjang pipa, ada pula yang dinamakan kerugian kecil (kerugian minor). Kerugian kecil ini disebabkan hal antara lain lubang masuk atau lubang keluar pipa, pembesaran atau pengecilan secara tiba - tiba, belokan, sambungan, katup dan pengecilan dan pembesaran secara berangsur- angsur.

Karena pola aliran dalam katup maupun sambungan cukup rumit, teorinya sangat lemah. Kerugian ini biasanya diukur secara eksperimental dan dikorelasikan dengan parameter parameter aliran dalam pipa. Kerugian kecil terukur biasanya diberikan sebagai nisbih kerugian hulu 
Belokan pada pipa menghasilkan kerugian head yang lebih besar dari pada jika pipa lurus. Kerugian-kerugian tersebut disebabkan daerah-daerah aliran yang terpisah didekat sisi dalam belokan (khususnya jika belokan tajam) dan aliran sekunder yang berpusar karena ketidak seimbangan gaya- gaya sentripetal akibat kelengkungan sumbu pipa.

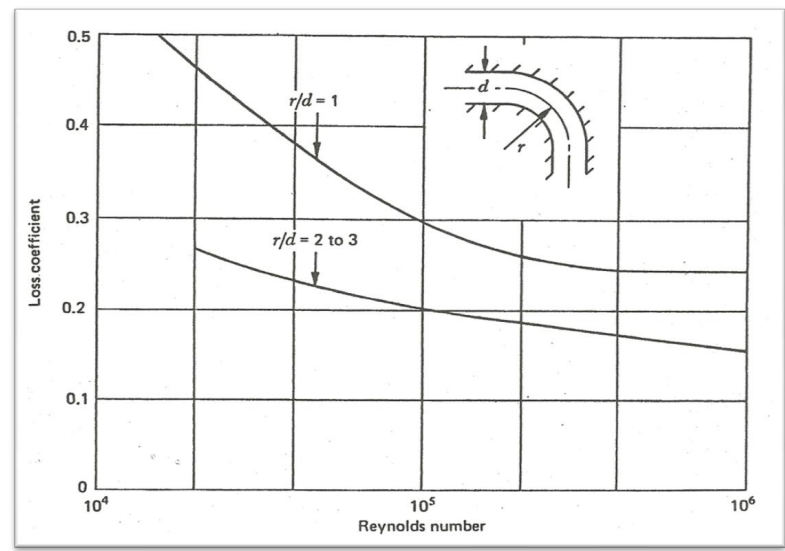

Gambar 1. Efek bilangan bilangan Reynolds terhadap koefisien kerugian pada elbow $90^{\circ}$ Berikut adalah grafik untuk menentukan koefisien kerugian untuk diffusers

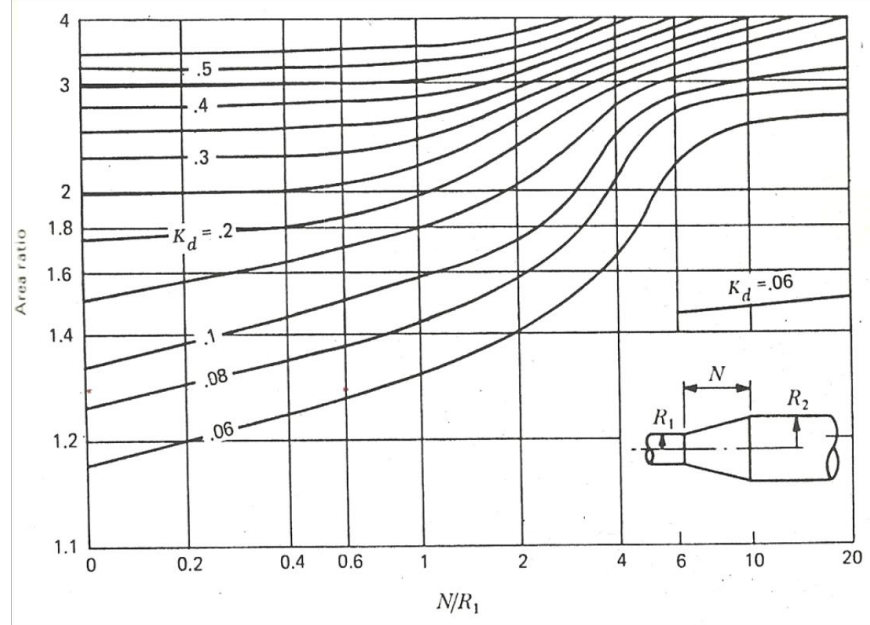

Gambar 4. koefisien kerugian untuk diffusers

Aliran yang melalui pengecilan kerucut tidak serumit dibandingkan aliran pada perbesaran kerucut. Koefisien kerugian yang khas berdasarkan pada kecepatan (laju tinggi) di sisi hulu bisa cukup kecil dari $\mathrm{K}_{\mathrm{L}}=0,02$ untuk $\theta=30^{\circ}$ sampai $\mathrm{K}_{\mathrm{L}}=0,07$ untuk $\theta=60^{\circ}$.

\section{Metode Penelitian}

Alat dan bahan yang digunakan :

1. Pompa digunakan untuk memompa air.

2. Pipa yang digunakan terdiri dari tiga jenis bahan yaitu stainless steel, galvanes, dan PVC.

3. Sambungan elbow $90^{\circ} 3 / 4$ " dimana pada ujungnya dipasang Reducer $3 / 4$ ' $\times 1 / 2$ "

4. Lem pipa digunakan untuk melekatkan pipa dengan sambungan.

5. Lem besi digunakan untuk melekatkan tapping pada pipa serta menutupi jika terjadi kebocoran. 
6. Manometer digunakan untuk mengukur besarnya tekanan statis.

7. Termometer digunakan untuk mengukur besarnya temperatur air.

8. Flowmeter digunakan untuk mengukur besarnya debit hingga mencapai besar debit yang diinginkan yaitu 15, 20, dan 25 liter/menit.

\section{Hasil dan Pembahasan}

Untuk mengetahui lebih jauh tentang penelitian yang diperoleh maka dilakukan perhitungan dengan mengambil salah satu contoh data yaitu pada pipa $\mathrm{PVC}$ dengan debit $\mathrm{Q}=$ 25 liter/menit. Adapun untuk data lainnya adalah sebagai berikut dan selebihnya diambil dari tabel dan grafik.

Data hasil pengamatan dengan debit aliran $\mathrm{Q}=25$ liter/menit dengan data- data sebagai berikut :

$\begin{array}{ll}\text { Debit ( Q ) } & =25 \text { liter/menit }=4.17 \times 10^{-4} \mathrm{~m}^{3} / \mathrm{s} \\ \text { h1 } & =3.86 \mathrm{mH}_{2} \mathrm{O} \\ \text { h2 } & =3.705 \mathrm{mH}_{2} \mathrm{O} \\ \text { Diameter masuk (Din) } & =0.866 \text { inch }=2.19964 \times 10^{-2} \mathrm{~m} \\ \text { Diameter keluar (Dout) } & =0.748 \text { inch }=1.89992 \times 10^{-2} \mathrm{~m} \\ \text { Sudut kelengkungan } & =90^{\circ}\end{array}$

Viscositas kinematis air pada $\mathrm{T}=26{ }^{\circ} \mathrm{C}=0,8832 \times \mathrm{m}^{2} / \mathrm{s}$

Jari - Jari elbow $(\mathrm{r}) \quad=2.19964 \times 10^{-2} \mathrm{~m}$

Dari data-data pengamatan yang telah diperoleh diatas maka dapat dihitung dengan menggunakan rumu-rumus berikut ini :

Sesuai dengan alat uji yang telah kami amati sebelumnya dimana terjadi pengecilan penampang pada elbow $90^{\circ}$. Adapun perhitungannya sebagai berikut

a) Luas penampang pipa

1. Luas Penampang (Ain)

$$
\begin{aligned}
A_{\text {in }} & =\frac{1}{4} \pi\left(d_{\text {in }}\right)^{2} \\
& =\frac{1}{4} * 3.14 *\left(2.19964 \times 10^{-2}\right)^{2}\left(\mathrm{~m}^{2}\right) \\
& =3.7981567 \times 10^{-4} \mathrm{~m}^{2}
\end{aligned}
$$

2. Luas Penampang Keluar (Aout)

$$
\begin{aligned}
A_{\text {out }} & =\frac{1}{4} \pi\left(d_{\text {out }}\right)^{2} \\
& =\frac{1}{4} * 3.14 *\left(1.89992 \times 10^{-2}\right)^{2}\left(\mathrm{~m}^{2}\right) \\
& =2.83361 \times 10^{-4} \mathrm{~m}^{2}
\end{aligned}
$$

b). Perbedaan tinggi aktual

$$
\begin{aligned}
\Delta h_{1-a c t} & =h_{1}-h_{2} \\
& =3,80-3,705 \\
& =0,155 \mathrm{~m}
\end{aligned}
$$


c). Kecepatan aliran masuk actual $\left(\mathrm{V}_{i n-a c t}\right)$

$$
\begin{aligned}
\mathrm{V}_{\text {in-act }} & =\frac{Q}{A} \\
& =\frac{4.17 x^{-4} 10}{3,7981567 * 10^{-4}} \ldots(\mathrm{m} / \mathrm{s}) \\
& =1.0970
\end{aligned}
$$

d). Kecepatan aliran keluar actual $\left(\mathrm{V}_{\text {out-act }}\right)$

$$
\begin{aligned}
\mathrm{V}_{\text {out-act }} & =\frac{Q}{A} \\
& =\frac{4.17 x^{-4} 10}{2.83361 * 10^{-4}} \ldots .(\mathrm{m} / \mathrm{s}) \\
& =1.470445 \mathrm{~m} / \mathrm{s}
\end{aligned}
$$

e). Bilangan Reynolds (Re)

$$
\begin{aligned}
\operatorname{Re}_{\text {in }} & =\frac{V_{\text {in } . D_{\text {in }}}}{v} \\
& =\frac{1.0970 *\left(2.19964 * 10^{-2}\right)}{0,8832 * 10^{-6}} \\
& =27321.1626 \\
\operatorname{Re}_{\text {out }}= & \frac{V_{\text {in } . D_{\text {in }}}}{v} \\
= & \frac{1.470445 *\left(1.89992 * 10^{-2}\right)}{0,8832 * 10^{-6}} \\
= & 31631.8825
\end{aligned}
$$

Berdasarkan bilangan Reynold yang telah didapat dari perhitungan diatas maka dapat disimpulkan bahwa baik aliran masuk maupun keluar alirannya adalah turbulent

\section{Pembahasan}

Dari hasil pengujian yang telah kami lakukan yaitu mengenai karakteristik aliran fluida akibat penyempitan dan perluasan pada sambungan elbow $90^{\circ}$, maka dalam bab ini kami akan memberikan analisis berdasarkan data-data pengukuran dan hasil perhitungan serta grafik dengan tujuan mempelajari kemungkinan- kemungkinan sesuai dengan tujuan yang ingin dicapai. Metode yang digunakan yaitu dengan membandingkan parameter yang satu dengan yang lainnya

1. Hubungan antara kerugian head aktual akibat penyempitan penampang elbow dengan perubahan kecepatan. 
Tabel 3. Penyempitan Penampang

\begin{tabular}{|l|c|c|c|}
\hline \multirow{2}{*}{\multicolumn{1}{|c|}{ Jenis Pipa }} & \multicolumn{3}{|c|}{ Debit (Liter/Detika } \\
\cline { 2 - 4 } & $\mathbf{1 5}$ & $\mathbf{2 0}$ & $\mathbf{2 5}$ \\
\hline STAINLESS STEEL & 1.1011 & 0.9291 & 0.8494 \\
\hline GALVANES & 1.8529 & 1.5407 & 1.3341 \\
\hline PVC & 1.8885 & 1.558 & 1.4050 \\
\hline
\end{tabular}

Naiknya kecepatan didalam instalasi khususnya disambungan elbow disebabkan karena terjadinya perubahan debit dan perubahan luas penampang aliran. Dimana kerugian yang terjadi semakin besar seiring bertambahnya debit aliran serta terjadi gesekan yang semakin meluas disepanjang dinding sambungan elbow yang terjadi akibat adanya luasan sambungan yang menimbulkan turbulensi ekstra yang meningkatkan kerugian head. Kenaikan kecepatan disertai dengan kenaikan kerugian head, dapat terlihat pada 1.

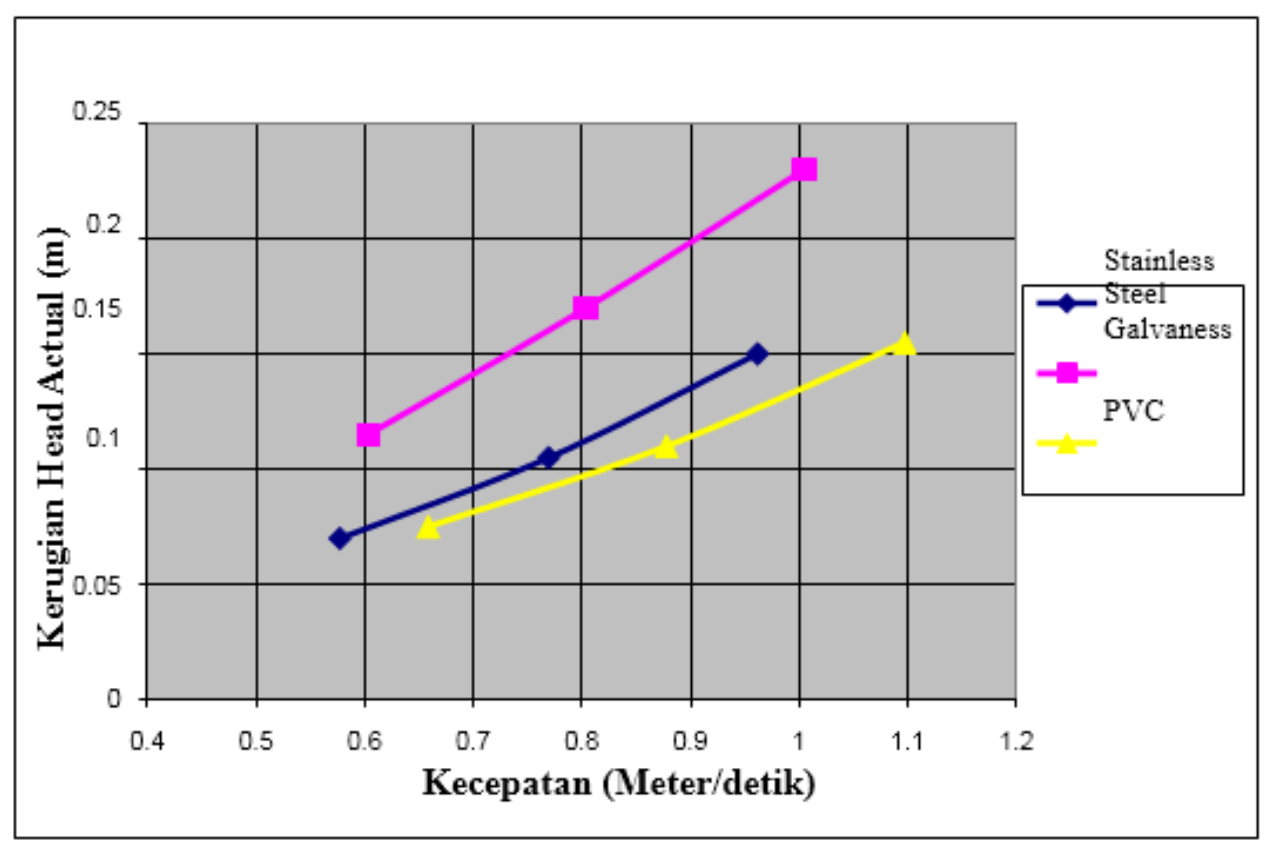

Gambar 1: Hubungan antara head actual akibat penyempitan penampang dengan perubahan penampang.

Semakin besarnya debit yang diikuti dengan kenaikan kecepatan aliran fluida akan memperbesar bilangan reynolds yang besar pengaruhnya untuk menambah kerugian head pada instalasi. Dengan naiknya kecepatan akibat penambahan debit maka kerugian viskos akan semakin berkurang sebaliknya kerugian head yang timbul akibat gesekan fluida dengan dinding pipa semakin besar pula. 
2. Hubungan antara kerugian head aktual akibat penyempitan penampang elbow dengan koefisien kerugian

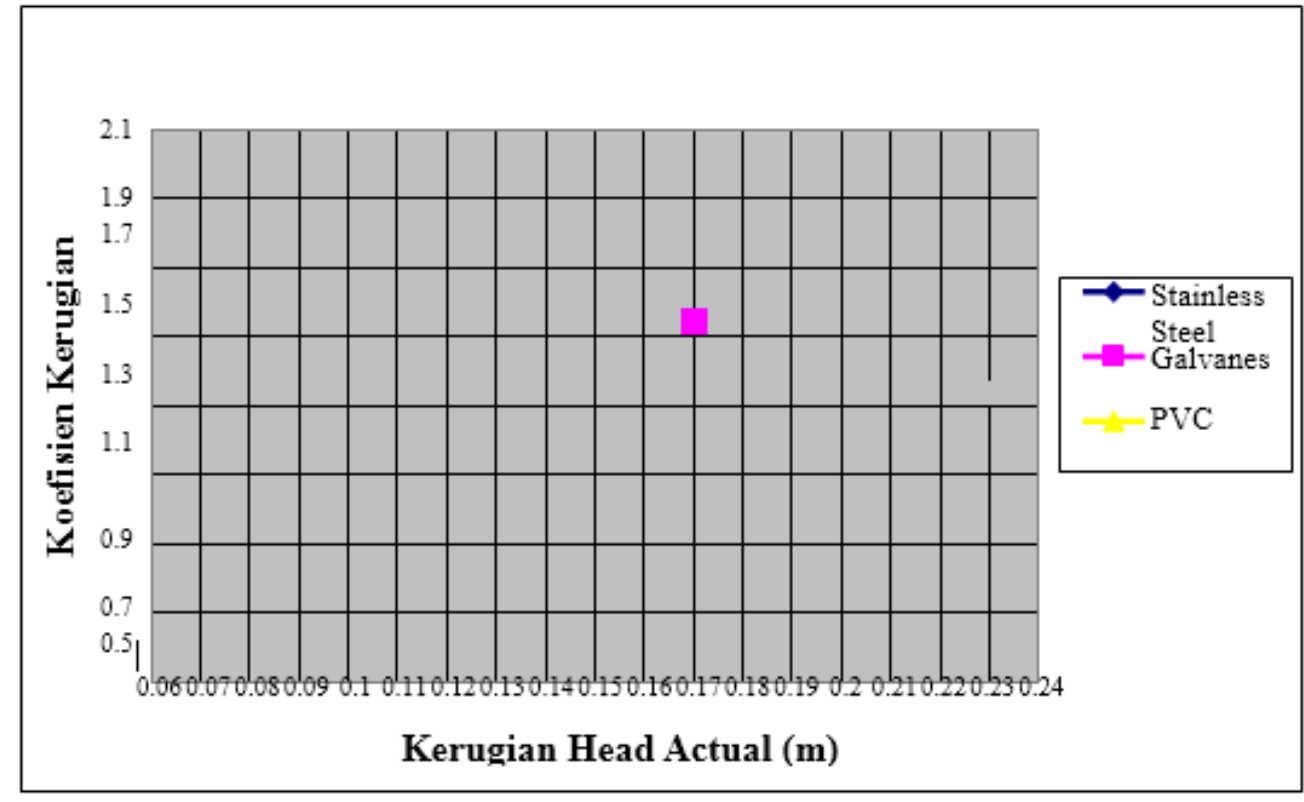

Gambar 2: Hubungan antara kerugian head aktual akibat penyempitan penampang elbow dengan koefisien kerugian

\section{Kesimpulan}

Kerugian akibat perluasan penampang elbow lebih besar dibanding dengan kerugian yang timbul akibat pengecilan penampang elbow 90o. Dimana K-act pada debit 25 liter/detik untuk pipa Stainless Steel yaitu penyempitan $=0,8494$ dan perluasannya $=$ 1.2719, untuk pipa Galvanes yaitu penyempitan $=1,3340$ dan perluasannya $=1,6510$, dan untuk pipa PVC yaitu penyempitannya $=1,4050$ dan perluasannya $=1,3029$. Perluasan penampang masuk terjadi pemisahan aliran serta pola aliran berubah-ubah yang menyebabkan pemisahan lapisan batas pada dinding. Hal ini merupakan gradien yang kurang menguntungkan meskipun tekanan statisnya naik

Perubahan debit juga mempengaruhi besar dari koefisien kerugian yang timbul dimana makin besar debit aliran maka kecepatan dan kekentalannya juga bertambah sehingga kerugiannya akan semakin kecil. Koefisien kerugian untuk pipa Stainless Steel pada debit 25, 20, 15 liter/detik yaitu penyempitannya $=0.8494,0.92907,1.10112$ dan perluasannya $=$ 1.272, 1.49057, 1.7666. Untuk pipa Galvanes pada debit 25,20,15 liter/detik yaitu penyempitannya $=1.3341,1.54073,1.8529$ dan perluasannya $=1.6511,1.82104,2.15826$. Dan untuk pipa PVC pada debit 25, 20, 15 liter/detik yaitu penyempitannya $=1.405$, $1.55802,1.8885$ dan perluasannya $=1.3029,1.52685,1.8096$. Penyempitan maupun perluasan penampang terjadi penurunan kerugian seiring bertambahnya debit, sehingga dapat disimpulkan bahwa koefisien kerugian berbanding terbalik dengan dengan debit.

Bilangan Reynolds dengan koefisien kerugian selalu berbanding terbalik.

Meningkatnya bilangan Reynolds disebabkan oleh diameter pipa/sambungan, debit dan kecepatan aliran dan viskositas fluida. Dengan bertambahnya debit aliran dapat menyebabkan naiknya kecepatan aliran serta bilangan Reynoldnya sehinnga koefisien kerugiannya menurun. Adapun nilai untuk Re dan K-act pada pipa Stainless Steel masing-masing yaitu $\mathrm{Re}=$ 
15347.43639, 20463.24853, 25579.06066 dan K-act $=1.101120518 ., 0.929070437$, 0.849435828. Untuk pipa Galvanes masing- masing yaitu $\mathrm{Re}=15686.60626,20915.47501$, 26144.34377 dan K-act $=1.490569414,1.821035147,1.526847208$. Untuk pipa PVC masingmasing yaitu $\operatorname{Re}=16393.04696,21857.39594$, 27321.74493 dan K-act =1.766600787, 2.158263878, 1.809596691. Data diatas memperlihatkan hubungan antara bilangan Reynold, koefisien kerugian, dan debit. Dimana faktor-faktor tersebut diatas yang kemudian mengurangi koefisien kerugiannya.

\section{Referensi}

[1] Raswari. 1986. Teknologi dan Perencanaan Sistem Perpipaan. Penerbit Universitas Indonesia, Jakarta

[2] Franzini Joseph B, Finnemore E. John. 2002. Fluid Mechanics. The McGraw- Hill Companies, Inc, New York.

[3] Haruo Tahara, Sularso, 2000. Pompa dan Kompresor. Pemilihan Pemakaian dan Pemeliharaan (Terjemahan). Cetakan ketuju, Pradnya Pramita, Jakarta

[4] Miller, D.S. 1978. Internal Flow Systems. BHRA Fluid Engineering, Cranfield, England

[5] White, Frank M., Manahan Hariandja. 1988. Mekanika Fluida (Terjemahan).

\section{Profil Penulis:}

$\begin{aligned} & \text { Ahmad Yani, Kelahiran Bima, 04 Desember 1987. } \\ & \text { Penulis merupakan Staf Pengajar Sekolah Tinggi } \\ & \text { Teknologi Industri Bontang dengan bidang keahlian } \\ & \text { Konversi Energi. Email: yanibima@gmail.com }\end{aligned} \mid \begin{aligned} & \text { Ratnwawati, Kelahiran Maros, 05 Agustus 1988. Penulis } \\ & \text { merupakan staf pengajar Sekolah Tinggi Teknologi } \\ & \text { Industri Bontang dengan bidang keahlian Konstruksi } \\ & \text { Mesin.. Email: azahabr@gmail.com }\end{aligned}$

